$1-1-1891$

\title{
Farm and garden insects : and experiments with remedies; Notes of the season
}

\author{
A. D. Hopkins
}

Follow this and additional works at: https://researchrepository.wvu.edu/ wv_agricultural_and_forestry_experiment_station_bulletins

\section{Digital Commons Citation}

Hopkins, A. D., "Farm and garden insects : and experiments with remedies ; Notes of the season" (1891). West Virginia Agricultural and Forestry Experiment Station Bulletins. 14.

https://researchrepository.wvu.edu/wv_agricultural_and_forestry_experiment_station_bulletins/14 @ WVU. It has been accepted for inclusion in West Virginia Agricultural and Forestry Experiment Station Bulletins by an authorized administrator of The Research Repository @WVU. For more information, please contact ian.harmon@mail.wvu.edu. 
West Virginia University Libraries

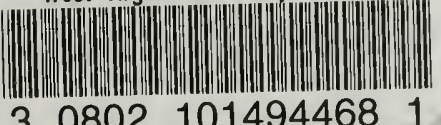





\section{Bulletin No. 14}

OF THE

\section{WFSI VIRGINIA}

\section{Agricultural Experiment Station} MORGANTOWN, W. VA.

\section{FARM AND GARDEN INSECTS.} AND EXPERIMENTS WITH REMEDIES.

\section{NOTES OF THE SEASON.}

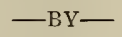

A. D. HOPKINS.

ENTOMOLOGIST.

$$
\begin{gathered}
\text { JOHN A. MYHPS, 12h. D. } \\
\text {, Dimectom }
\end{gathered}
$$

FEBRUARY, 1891 .

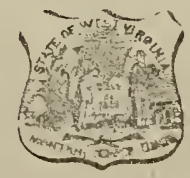

UHARLESTON, W. VA. Moses W. Donnally, Publin Printien. 


\section{BOARD OF REGENTS OF THE WEST VIRGINIA UNIVERSITY,}

Distriet.

Name of Regent.

J. B. SOMMERVILLE, CLARENCE L. SMITH, PEREGRIN HAYES, D. D. JOHNSON, JOHN G. SCHILLING, EDWARD A. BENNETT, WIRT A. FRENCH, M. J. KESTER, J. F. BROWN, THOS. J. FARNSWORTH, JOSEPH MORELAND, JOHN A. ROBINSON, DR. W. W. BROWN,
P. O. Addresi.

Wheeling.

Fairmont.

Glenville.

Long Reach.

Spencer.

Huntington.

Princeton.

Union.

Charleston.

Buckhannon.

Morgantown.

Patterson's Depot.

Kabletown.

\section{MEMBERS OF THE STATION COMMITTEE.}

JOHN A. ROBINSON, JOSEPH MORELAND,
JOHN G. SCHILLING, THOS. J. FARNSWORTH, DR. W. W. BROWN.
President of the University.

E. M. TURNER, LL. D.,
Treasurer.

JOHN I. HARVEY.

\section{STATION STAFF.}

JOHN A. MYERS, PH. D., CHAS. F. MILLSPAUGH, M. D., Botanist and Microscopist. A. D. HOPKINS, D. D. JOHNSON, A. M., Sp'l Agt. Entomology. RUDOLPH J. J. LE ROODE, Pн. D., . . Chemist SUSIE V. MAYERS, : : Stenographer and Ponk keener. 


\section{FARM AND GARDEN INSECTS. 2. NOTES OF THE SEASON,}

A. D. Hopkins.

In assuming the duties with which $I$ have been charged the investigation of injurious and beneficial insects, and in making a collection of those found in the State, I do so with a conviction of the great importancc of such studies in promoting the agricultural interests of the State.

Recognizing the importance of a full reference collection as one of the first requisites for doing good work in this new line of research undertaken by the Station, I have devoted considerable time to collecting specimens, which are being preserved in alcohol and papers until the winter months, when they will be properly mounted, determined, and arranged in cases, which are now being prepared for their reception.

Special investigations and experiments have been conducted as Follows: Experiments with remedies for the Cabbage Flea Beetle, Plum Curculio, Sheep Ticks, House Flies and Currant Worm. Special investigations on a raspberry insect, Locust tree insects and the desrtuciion of the spruce forests.

Between the 2 nd and 26 th of July a trip was made through a portion of the State, in company with the Botanist, for the purpose of making collections, and to find out if possible, from personal observations, the agricultural conditions of our State, and the wants of the farmer in our respective departments. The trip was very successful and satisfactory in both respects. A large and valuable addition was made to the collections, and the knowledge gained will aid us very materially in directing our work where it will do the most good.

It is my intention to continue to add material to the collection whenever opportui:ity offers, and when I am not otherwise engaged, until a reas.nably complete reference collection of the injurious, beneficial and other insects of the State is made. In addition to a study collection, I desire to form an exhibit collection to illustrate the different orders and families of insects, their wonderful transformations and modes of attack, their parasites and natural enemies, their remarliable instincts, and the provisions of nature in making 
the conditions favorable for their existence. In this exhibit collection, only material of economic interest will be placed; the object being to interest the farmer ir the importance of this branch of study, and thus gain the benefit of their observations and their indispensable aid in suppressing the insect pests of the State. I hope to be able to adopt a system of correspondence with farmers and others in different sections of the State, that I may be informed at as early a date as possible as to the appearance of injurious insects, and the amount of damage they may be doing to crops and forest trees, and when the amount of damage is known to be of sufficient magnitude to warrant my going into the region effected for the purpose of making special investigations of the insects, their habits and natural enemies, experiment with insecticides, and give instructions in the application of remedies, I shall do so, believing that in this way the most valuable results may be obtained in this department.

I shall continue my investigations and experiments on cabbage, locust tree and spruce tree insects, taking up one at a time in the proper season, continuing from year to year if necessary, and will give the result of my original observations and experiments in special bulletins for each investigation, so illustrated and described that the farmer will readily recognize the injurious insects and their natural enemies in their different stages and transformation, and know when and how to apply the proper remedy to obtain the best results.

In my investigations, special attention will be given to the parasites and natural enemies of injurious insects, with reference to their habits, protection, encouragement, and introduction from one locality to another. In the case of wide-spread destruction of forest trees and like ravages, this seems to be the only practicable remedy to be thought of.

My reports of investigations will be addressed to the farmer and general reader, avoiding as far as possible technical terms and descriptions.

"By the census of 1880 , we find that the aggregate loss from insects in the United States equals $\$ 200,000,000$ a year, while good authority places the loss one-half higher." The loss, therefore, from their depredations in West Virginia is not less than a half million dollars each year, or at least as much as the total annual tax collected in the State; a loss, which in the present state of agricultural depression, is ceeply felt by those depending upon the products of the farm.

"There are over $3=0,000$ known and described species of insects in the world; over 25,000 of them being in the United States; of which 7,000 to 8,000 are pests." It is, therefore, safe to estimate that there are over 20,000 known and unknown species of injurious and beneficial insects in West Virginia.

We realize the importance of a better knowledge of our insect enemies and friends when we consider that the life history of only a few of our commonest insects is well known, that without a knowl- 
edge of the complete life history of an injurious insect in all its transformations, we can not successfully combat it; and that without a knowledge of the habits of an insect and its natural enemies, we may often do more harm than good in recommending or applying remedies.

The study of the habits of a single insect throngh its transformations ; the egg, how, when and where depositied; the larva or worm; its habits of feeding; its natural enemies ; when and where it changes to the pupa; duration of the pupa state; when the perfect insect emerges; how it passes the winter and its habits up to the time of depositing its eggs "often involve earnest, long, and patient study and the united labors of individuals extending over a series of years." When we consider the many thousands of beneficial and injurious insects of which the life history is not known, we realize the magnitude of this field of investigation, and the need of earnest workers in every State and intelligent observers on every farm, all working together for the advancement of knowledge in economic Entomology.

Less than a century ago, the study of insects was ridiculed by nearly every one, and even yet, it is ridiculed by many of those whom it would benefit most. The study has, however, assumed great importance within the last few years in its direct application to advancing the agricultural interests of the country. With the Division of Entomology at Washington, the U. S. Entomological Commission sustained by liberal appropriation, the State Entomologists employed by a number of the States, and the Experiment Station workers in Entomology of which there are now about thirty, we may look for the most rapid progress, and valuable results within the next few years.

\section{FARM AND GARDEN INSECTS.}

Having been supplied with a complete outfit for testing and experimenting with remedies, I have made such experiments and tests as the conditions would justify.

For the benefit of those who are not acquainted with the transformations and habits of insects, I will give an outline history of each insect on which remedies have been tried. The common name will be given first, followed by the technical name.

THE STRIPED FLEA BEETLE OR CABBAGE FLEA.

\section{(Phyllotreta Vittata Fab.)}

This well known garden pest appears early in the spring, destroy ing cabbage, radish and turnip plants before the second leaf is formed, and feeding on the leaves of the same through the summer. The beetles deposit their eggs in the stem and roots of cabbage and radish plants, the, eggs hatch into minute worms which feed upon the roots and stem causing the plant to wither and die as if 
scorched by the sun. Frequently as many or more plants are killed by the worms or larvæ as is destroyed by the beetle.

Great loss is sustained by farmers along the Ohio river from the ravages of this insect where millions of plants are grown in open fields.

On April 23rd, this beetle made its appearance on my cabbage and radish plants. I at once commenced a series of tests and ex-

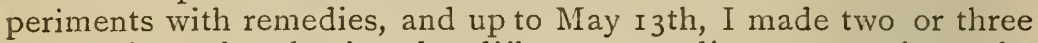
applications of each of twelve different remedies upon a plant, the rows of which were divided into sections, part of them being left as checks.

\section{Remedy No. I. (Original.)}

$1 / 2$ gallon of water. Two table-spoons soft soap. I table-spoonful pyrethrum. I table-spoon carbolic acid. 2 table-spoons tabacco dust. Applied April 23rd, with garden syringe, $1 / 2$ of the mixture to $30 \mathrm{ft}$. row of radish plants badly infested. In a short time the beetles were found lying on their backs apparently dead. Ten beetles thus affected taken in a bottle revived within an hour. Beetles did not feed on the treated plants until the remedy was washed off by rain.

\section{Remedy No. 2. (Original).}

Lime I pint.

Ashes I pint.

Plaster $1 / 2$ pint.

Tobacco dust 6 table spoons.

Carbolic acid I table spoon.

I-2. of this mixture was applied to $30 \mathrm{ft}$. row of cabbage plants. $3 \mathrm{ft}$. left without remedy. Rained directiy after making application. April 25 th, no difference observed in treated and untreated. This would probably be a good application to make every morning in dry weather. Three more applications were made between April 23rd and May I $3^{\text {th. }}$ It rained directly after each application. Result same as above.

\section{Remedy No. 3}

Composted hog manure dusted around radish plants. This had the effect of making a rapid growth of plants thus preventing injuring from beetles to some extent.

$$
\text { Remedy No.4. (Original.) }
$$

2 qts. water.

I handful tobacco dust.

I tablespoon carbolic acid.

I teaspoon paris green. 
I pint soft soap.

Applied full strength killed the plants.

Diluted $1 / 4$ killed the plants.

Diluted $\pi / 2$ scorched them.

Diluted $3 / 4$ had the effect of keeping beetles away until the remedy was washed off by rain.

\section{Remedy No. 5. (Original.)}

Saw-dust impregnated with natural heavy West Virginia oil. Saw-dust $1 / 2$ gallon. Oil $1 / 2$ pint.

Applied I qt. of mixture to $30 \mathrm{ft}$. row of cabbage plants. This proved a good preventive for a few days.

\section{Remedy No. 6. (Original.)}

Saw dust I qt.

Turpentine 3 tablespoons.

Carbolic acid I tablespoon.

Applied to $30 \mathrm{ft}$. row of cabbage.

More beetles were found on this row than on No. 5, but not so many as on check rows.

\section{Remedy No. 7 .}

Applied I pint of soot from wood fire chimney to I $5 \mathrm{ft}$. row of cabbage plants. Two applications, between May 8th and I $3^{\text {th. }}$ Rained after making each application. Result: Beetles found on treated and untreated alike.

\section{Remedy No. 8.}

Wood ashes, I pt. Applied to I $5 \mathrm{ft}$. row radish and $15 \mathrm{ft}$. row cabbage plants. Condition and result the same as No. 7 .

$$
\text { Remédy No. } 0 \text {. }
$$

Tobacco dust, I tablespoon applied to I $5 \mathrm{ft}$. row of cabbage plants. Condition and result same as No. 7.

Remedy No. IO.

Poultry manure, I qt. applied to $15 \mathrm{ft}$. row of cabbage plants. The plants grew better, but the result as to injury from beetles about the same as No. 7 .

\section{Remedy No. II.}

Pyrethrum (or insect powder) I tablespoon applied to I $5 \mathrm{ft}$. row of cabbage plants covered with beetles; this seemed to kill them. Nine beetles, howevor, taken in a bottle revived within an hour. 
Remedy No. I2.

Pulverized dry dirt dusted over plants. This had no effect again on account of rain.

$$
\text { ¿Summary. }
$$

On account of frequent rains during the time of making tests, it was impossible to arrive at definite conclusions. Owing to the fact that frequent rains are favorable to the growth of cabbage and radish plants and unfavorable for the life habits of the flea beetle, the untreated or check rown fared almost as well as those that were treated. The experiments proved, however, that liquid applications like Nos. I and 4, and disagreeable odors like 5 and 6, would probably be the best remedies to use in wet weather. Nos. 2, 7, 8 , 9 , II and I 2 applied in the morning while the plants are wet with dew, in dry weather would probably be good remedies. The liquid applications should always be applied in the evening.

The most favorable conditions for the life habits of the Flea Beetle is a bed of cabbage plants in an exposed dry and sunny spot, disturned only occasionally by rain and the cultivator. To successfully combat the pests, therefore, we must reverse these conditions as far as possible by selecting damp shady spot for the plants, cultivating frequently and watering often if necessary.

SHEEP TICK.

\section{(Meliphagus Ovinus Linn.)}

This well known sheep parasite is found in the wool at all times in the year. According to Packard, (Common Insects page 85). "The young are developed in the body of the parent insect, and instead of an egg, a pupa case is deposited containing a young tick. These pupa cases are found in the wool resembling brown seeds. Each female produces but two or three young," therefore, they do not increase readily, When very numerous they cause the sheep to fail in flesh. In Spring before and after the sheep are shorn, they leave the old ones and attack the lambs, checking their growth and preventing their fattening, causing great loss to the grower of mutton lambs.

On April 25th, I applied the following original mixture as a remedy for ticks on lambs. Salt 8 table spoons, Tobacco dust 8 table spoons, Sulphur 4 table spoons, Pyrethrum 2 table spoons. Mixed and applied dry to twenty lambs when wet with dew. The wool opened and the mixture sprinkled and thoroughly rubbed in with the hand.

On April 26th, I examined the lambs and found nearly every tick dead. This mixture should be applied to the sheep in the fall and spring and to the lambs when one to three months old. 
THE PLUM CURCULIO.

Conotrachelus Nenuphar Herbs.

This small, rough, grayish beetle is about. 15 of an inch long and feeds on the leaves and green fruit of the plum, apricot, peach, cherry apple and quince. It deposits eggs in the young green fruit in which the larva or worm develops, causing the fruit to fall off, "when the larva emerges and enters the ground, where" it changes to the beetle in about six weeks." "Coming from the ground it hides in some secluded spot under chips and bark until the following spring; when it comes forth to again feed and deposit its eggs, appearing at first only at night. Later it may be found on cloudy days on the fruit and twigs. It is very timid and will curl up and fall off the tree when alarmed. Its habit of feeding on the fruit and leaves enables us to kill some of them by spraying the trees with poison liquids, and their falling from the tree when alarmed enables us to collect and destroy them by jarring them off on sheets spread under the tree. To prevent injury to the tree when jarring, a branch should be cut off leaving a stub on which to strike with a mallet or hammer. This jarring process should be commenced about the time the blossom falls and continued until about the first of July. The jarring should always be done late in the evening or early in the morning. When, however, there are a number of trees sufficient to justify the purchase of a spraying outfit, it may be better to spray the trees with a poison solution of Paris Green and London Purple. If the Plums or Cherries are affected with mildew or rot it is well, perhaps, to add a mixture of copperas and lime or soda carbonate to the poison solution.

The proper poison mixture is about $1 / 4 \mathrm{lb}$. of London Purple to 50 gallons of water: to which may be added for the mildew or rot 4 lbs of sulphate of copper and $5 \mathrm{lbs}$. of soda carbonate.

Nearly all the fruit in this section was killed by late frosts. This, with the unusual wet weather, made an unfavorable season for making tests or experiments with remedies for the curculio. I had, however, a few cherry trees that were in full bloom, and on May I 5 th, just after the blossom fell from the tree, I applied about ten gallons of the above mixture on a large cherry tree on which the cherries had been badly affected in previous years by the curculio and mildew. On May 25th, I examined the cherries on the sprayed and unsprayed trees, finding many stung cherries on the unsprayed.* but none on the one that was sprayed. On May 28th, the cherries commenced to rot and the rose bugs were observed eating the cherries on the treated and untreated alike. A few cherries on the sprayed trees were stung by the curculio. On June and I made another application of the same mixture to the same tree. The rose bugs continued to eat the cherries; but no further attack of the cur-

*The nearest unsprayed cherry tree to the one that was sprayed was about 100 yards. 
culio or rot could be found. The cherries on the unsprayed trees were so badly affected by the curculio, rose beetle and an Hemipterous insect, that scarcely a cherry remained on the trees to ripen.

The sprayed tree remained full of cherries until he first ones began to turn red, when over two-thirds of them fell off covering the ground with the fallen fruit. No worms could be found in the fallen fruit, and the cherries that remained on the tree were also free of worms. The fallen fruit showed evidence of punctures of the Hemipterous bug, which probably caused them to fall.

While the above experiment was incomplete, it was sufficient to prove that it would probably pay well to apply the mixture to cherry trees subject to the attack of the curculio or rot.

THF: COTLING: MOTH.

\section{(Corpocapsa Pomonella Linn.)}

This insect was imported from Europe about the year 1800 and is now found wherever apples are grown in North America, causing an immense loss to fruit growers. It is a very small chocolate colored moth, appearing in the spring when the apples are in bloom, depositing their eggs in the blossom end of the fruit when about the size of peas. In about a week, the eggs hatch into a small pinkish worm, which bores into the apple and feeds around the core until it arrives at maturity, when it escapes from the apple either betore or after it falls from the tree, after which when they construct their pupa cases or cocoons under the rough bark of the tree, where they change to the pupa, which remains in the cocoon about two weeks, when the moth emerges to again deposit eggs in the more mature fruit late in July or early in August, this being the second brood of worms; the first brood causing the young apples to fall from the tree, the second braod spoiling the mature apples for market and making them "wormy" and imperfect. The worms are carried to the cellar in the apples where they escape and spin their cocoons in which the worms or larvas spend the winter changing to the pupa early in the spring from which the moth soon emerges.

Two parasites of this insect were bred and described by Prof. Riley. These parasites deposit their eggs in the worm, which hatch into small grubs and devour their host.

There are also birds and other insects which attack and feed upon the worms after they escape from the apple.

\section{Remedies.}

By keeping sheep or hogs in the orchard to eat the fallen fruit, many of the worms may be destroyed. The best remedy however, is to spray the trees with a poisoned liquid during the time the moths are dositing their eggs. A very small amount of this poisoned liquid catching in the blossom end of the young apples is sufficient to kill the young worms when they hatch and commence to feed. 
Paris Green, or London Purle is used for this purpose. Prof. Cooke of Michigan who has tried many experiments with this remedy with excellent results, recommends I pound of the posion to 200 gallons of water.

To prove that no bad effect would result from stock eating the grass under a tree after it had been sprayed with this poisonous liquid, he cut the grass under a tree thus sprayed and fed it to his horse; this did not even make the animal sick. By analysis it has also been found that there is not a sufficient amount of poison adhering to the fruit or grass to injure animals.

On May I $4^{\text {th }}$, June 2 nd and I $3^{\text {th }}$, I sprayed four apple-trees, using the same mixture with which I sprayed the cherry tree. The rose beetles were very plentiful on the trees, eating the fruit at the second spraying; but the liquid did not seem to have much effect on them. They continued to eat the apples on the sprayed and unsprayed trees alike.

On account of other pressing duties and absence from home, I could not make a thorough examination of the fruit when it ripened; but as far as I could judge from a hasty examination, the fruit was much less affected by worms or rot on the sprayed trees than on the unsprayed. I hope to make farther and more complete tests next spring.

In applying the remedies upon both the cherry and apple trees, the "Perfect Spraying Outfit" was used, which is a hand force pump attached to a barrel containing the mixture. It has ten feet of discharge hose with a graduated spray nozzle attached. An arrangement is also attached for agitating the mixture in the barrel while spraying. With this outfit placed in a wagon, the hose tied to a long pole, and an assistant to drive the pump, every part of the largest trees may be thoroughly sprayed.

THE IMPORTEI CURRANT WORII.

\section{(Nematus Ventricosus Klug.)}

This is a very common insect throughout the State of which much complaint has been made the past summer. It is a fly about the size of a house-fly, but belonging to a different order of insects. They appear early in spring and deposit their eggs on the veins on the under side of the leaf in regular rows. These hatch into the now familiar worms in about four days. These continue to feed about eight days, after which they leave the bush and seek a sheltered spot, or enter the ground, where they spin their cocoons in which they change to the pupa, remaining thus about I 3 days, when the fly emerges to deposit eggs for another brood of worms, which, after coming to maturity pass the vinter in their cocoons, the flies appearing again in the spring.

Prof. Linter, of New York, discovered a parasite which attacks the eggs, causing them to turn brown. In other localities an ichneumon parasite attacks the worm, while the soldier bug (one of 
the stink bugs) "destroys the lava by thrusting its beak into the victim and sucking it until it shrivels up and dies.

On May 2oth, powdered white helebore applied dry with a bellows to gooseberry bushes infested with the worms proved to be an excellent remedy, killing nearly every worm the first application. This remedy applied dry or in solution of about an ounze to two gallons of water, is probably the best remedy known.

Rose slugs, cherry and pear slugs belonging to the same family as the currant or gooseberry worm-may be successfully destroyed by the same remedy.

THE HOUSE FLY.

\section{(Musca domestica Lin.)}

This is our commonest household pest, familiar to every one as they see them; but a mystery to most people as to where they come from. Like all other insects, it is first an egg, then a worm, larva. or maggot, then a pupa or inactive form from which the fly emerges. During the first warm days of spring, this fly comes forth from its: winter sleep, having passed that season either in its perfect state or as a pupa; they then commence to deposit their eggs in stable manure, and decaying vegetable substances. The eggs hatch in about twenty-four hours into a little maggot, which feeds upon these substances coming to maturity in about a week, when they accumulatein great numbers in a dry spot and change to the pupa. When they resemble little, red eggs, the size of small wheat grains. They remain thus about a weak, when the perfect flies emerge to again deposit their eggs, in this manner there is a number, probably a dozen broods within a year.

They are sometimes attacked by a disease called the "Fly Cholera," a vegetable parasite or fungus, which destroys great numbers. When thus affected, they may be found attached to the wall or window pane, surrounded with a white halo of the spores. An insect parasite also attacks them in their larval state, living within their host until after the fly larva changes to the pupa, when, instead of: the fly emerging, a minute gnat or chalcid fly will come forth. They also have a great many other insect and animal enemies.

Perhaps the best preventative against this pest is to keep everything about the house and outbuildings scrupulously clean, not allowing manure of any kind, or decaying vegetable matter, to remain in once place longer than ten days during the spring and summer months. Such matter should be scattered out on fields and gardens: where it will do the most good. A compost heap proves a hot bed: for flies unless sufficient lime or plaster is added to kill the larvæ. Beneath stable floors is also a nursery for these little pests.

During the summer, I made frequent tests with insect powder (pyrethrum), blown freely in the air of a closed room with the Woodson Insect Powder Bellows, which proved this method to be one of: the best remedies for stupefying the flies. When thoroughly done; 
(if the powder has not lost its strength), the flies may be swept up and burned within an hour after the powder is used, if allowed to remain longer many of them will recover.

\section{COLLECTING TRIP NOTES.}

Between July $2 \mathrm{~d}$ and $26 \mathrm{th}$, 1890 , a journey was made by team and wagon throughout eleven counties of the State, in company with the Botanist of the Station; the route being from Parkersburg up the Little Kanawha River, through Wood, Wirt, Calhoun and Gilmer counties, thence on the Parkersburg and Staunton pike through Lewis and Upshur counties over Rich Mountain to Beverly, and up the Valley River through Randolph county to Valley Head ; thence over Point and Buffalo Bull Mountains, down Elk River to Addison; thence over Elk Mountain through Webster county into Nicholas county ; thence down the Gauley and Big Kanawha River through Fayette and Kanawha counties to Charleston; thence by the Charleston and Parkersburg pike through Kanawha, Jackson and Wood counties to Parkersburg, being a distance of 376 miles. Copious notes were taken of observations all along the route of which the following is a summary:

\section{COLORADO POTATO BEETLE.}

This beetle which has in past years been so destructive to the potato crop in this State, was observed to be doing very little damage all along the route, and it was reported that within the last year or two this insect seemed to be disappearing. This, no doubt, is caused by the increasing number of its natural enemies, which were found quite plentiful among the vines. Prominent among these were the lady birds, (little red bugs or beetles with black spots), a number of species or which were observed devouring the eggs and young larvæ of the pototo beetle.

\section{CURRANT OR GOOSEBERRY WORM.}

The destructive work of this insect was noted through all the counties except portions of Gilmer, Fayette, Kanawha and Jackson counties.

THE WHITE GRUB.

This pest, the larva of the May beetle, (which is so plentiful at night, during May, feeding on the leaves of fruit and forest trees), was reported in every county passed through as doing great damage to grain and grass crops. ' In the Tygart's Valley in Randolph and through portions of Webster and Nicholas counties, their damaging effect upon the corn was very noticeable. 


\section{$; 6$ \\ WIRE WORMS.}

These are the larvæ of several species of snapping or click beetles, and like the White Grub are found to be doing immense damage to corn crops, especially in the low lands of Tygart's Valley and Welch Glades. One farmer near Beverly reported that he had re. planted his corn three times and the wire worms ate it up each time before it came up. He then soaked his corn in tar water, when he got a partial "stand," but too late to make a crop. It was also reported here that the worms were much worse on corn where hay and straw had been previously fed out on the land. Another farmer near the head of the valley had tried Buckeye Phosphate in the hill as a remedy for Wire and Grub Worms on corn; but the results were not satisfactory.

The Wire and Grub Worms are without doubt among the worst insect pests the farmers of this State have to contend with. Hidden as they are beneath the surface of the ground and feeding on the roots of the grain and grasses, and on the roots of nearly every kind of vegetation. I have frequently observed in my practical experience on the farm that an application of different kinds of stable manure and plowed under on land infested by these insects has proven doubly beneficial in stimulating the crop and repelling or killing the worms. It is, therefore, my intention to visit the worst infested districts next spring for the purpose of studying these insects, and to conduct a series of experiments with different kinds of fertilizers to ascertain their value as insecticides, and I would suggest that farmers generally note carefully the effect on these insects, of different kinds of fertilizers; especially stable manure plowed under for corn, and report results to the Station.

THE CABBAGE WORM.

Of the White Butterfly (Pieris rapae) was reported all along the route as not doing as much damage to the cabbage as triey had in former years, and the Butterfly was noted as being rare.

A new Cabbage Worm, which is probably the larvae of the Cabbage Pionea (Pionea remasalis) was reported and observed to be doing considerable damage to cabbage near Charleston and Parkersburg. It has since been observed at Morgantown, ar d was recently sent to me from near Amenia, Washington county, $O$. This is a southern insect and is probably being introduced here in southern cabbage. I find, however, that a parasite is destroying this insect in great numbers, which will probably prevent it from becoming a serious pest.

THE APPLE-TREE TF.NT-CATFRPILLAR.

The webs of this insect were observed plentiful in apple trees in portions of Wood and Upshur counties, and occasionally at points in other counties passed through; the trees having in places been 
defoliated by the caterpillar. The eggs from which these caterpillars hatch are deposited in July by a moth or "miller" in groups of two or three hundred, on small twigs, resembling black knots. These may, without much diffiulty, be found and destroyed during the winter, and thus prevent the caterpillar from appearing in the spring.

'THE. STOLK-BOREK OR "HEARY-WORM."

This is a brown or black striped worm which was frequently observed feeding in the heart of young corn, in the stalks of uron weed, thistle, rag weed and young blackberry briars; in fact they were found in nearly every kind of weed and plant having a pithy stalk. They were found to be doing considerable damage to corn in Randolph and Webster counties.

THE GRAIN PLANT-LOUSE

Was generally complained of, and probably did considerable damage to wheat and oats early in the season; the latter crop being almost a failure in all the counties passed through. A number of parasites were found attacking this insect, which no doubt prevented a total destruction of the wheat and oats crop.

THE PEACH TREE BORER.

Was found to be generally destructive to neglected peach trees. Fresh wood ashes placed around the trees in May of each year has been found an excellent remedy against the attack of this insect.

THE APPLE TREE BORER.

This insect was found to be doing much damage to apple trees in Upshur county, near Buckhannon. One of the best remedies for this insect, perhaps, is to place fresh wood ashes around the roots of the trees in May and July of each year and hang rags or pieces of old carpet satuated with soft soap in the forks of the trees. This, like the above remedy for the Peach Tree borer is, however, only successful as a preventative. After the Grubs are once lodged within the wood, they must be either cut out with a knife or killed by inserting a wire into their burrows.

TOBACCO INSECTS.

Through the "Lime Stone Hill" region in Jackson and Wood Counties, where tobacco is one of the principal crops grown, the insect complained of was the Tobacco Worm, which had been giving unusual trouble.

There is a parasite attacking this worm, and if the worms thus attacked were left to breed them, the insect would probably soon 
disappear without much effort on the part of the tobacco grower. The worms thus affected may be known by their unhealthy appearance and the great number of little white cocoons on their backs, each one of which contains a parasite.

\section{SPRUCE INSECTS.}

While passing through Randolph County, we first learned of the destruction of the Spruce timber in Cheat Mountains, the cause of which no one seemed to know. It was reported that hundreds of acres of the timber was continually dying and that the trouble was constantly increasing. When we learned of the immense extent of the forests covering some five hundred thousand acres, and that it was probably threatened with total destruction, possibly by disease or insects, we decided that on returning to the Station, we would urge the importance of a special trip to this region for the purpose of investigating the trouble. Accordingly a trip was made into this region the last of August, an account of which will follow.

\section{A NEW WHEAT INSECT.}

A new wheat insect was reported near Elizabeth in Wirt County, operating in the stalks, causing them to fall or lodge before the grain ripens. The crop being gathered, observation on the species causing the trouble was impossible.

\section{A NEW CORN INSECT.}

A new corn insect was reported near Charleston to have done considerable damage to the crop early in the season. It was a "small white worm" or "maggot" operating near the roots of the young corn.

A new Gooseberry Bug or Beetle was reported near Mount Carmel, in Fayette County. A "small bug" had eaten all of the leaves and fruit off the bushes.

A rabbit was found in the road in Jackson County having evidently died from the effects of a parasite which, upon examination, was found in a large tumor on its neck. It has been noticed for a number of years that the rabbits in the vicinity of Kanawha Station during July and August were seriously affected from the attack of this parasite. They became so weak and emaciated that they could not run and dogs would kill great numbers of them.

A day was spent with Mr. W. H. Edwards at his home in Coalburg, Kanawha County. Mr. Edwards has spent many years in the study of the Butterflies of North America, and his work and writings have made his name familiar to Entomologists in this and other countries. The butterflies taken by me up to that time were kindly determined by him. I an also indebted to him for later determination.

The specimens taken during the trip, are all yet in alcohol and 
papers, where they will necessarily remain until a cabinet is prepared and time can be had to properly mount and determine the material. A list of the species taken on this trip will appear later.

It will be seen from this report that there is a broad field for work in this Department. That this trip has pointed out lines of work in which results should yield the greatest benefit to the farmers and to the State, and that to obtain such benefit, special investigations must be made in the localities in which the greatest damage is being done by cerlain insect pests.

THE HORN FLY.

On returning to Kanawha Station on July 26 th, this was observed for the first tinue on my cattle, and on inquiry it was found that they were annoying other cattle in the neighborhood, which was creating considerable comment as being something new. Prof. John B. Smiths' excellent account of this fly in a special bulletin of the New Jersey Expermiment Station and in the Annual Report of the same for I 889 , enabled me to recognize this insect brought over on cattle about the year I886-1887. It was reported from near Philadelphia in 1887 and by the middle of July, 1889 it had spread nearly all over the State and southward into Virginia and northward into New Jersey.

The fly will be readily recognized where they make their appearance by their great abundance on the body and horns of the cattle. The resemble the common house fly, being abont half as large. They are blood thirsty little insects and so annoy the cattle by their bites that the cows fail in milk and other cattle fail in flesh.

On October Ioth, the flies were again observed at the same place and more complaint was heard in regard to them.

On September $\mathrm{r}$ th, my home was again visited, when a Jersey cow was found to have large bleeding sores on each side, exidently caused by the irritation of the flies and kept bleeding by the cow striking or rubbing the places with her horns.

According to Prof. Smith, these flies breed in the fresh droppings of the cattle a new brood appearing every fifteen days. Prof.. Smith recommends as as remedy against the attack of the flies, fish oil, with a small amount of carbolic acid applied with a sponge, or X $\mathrm{O}$ Dust and Tobacco Dust applied to the cattle among the hair where the flies most usualy congregate.

These flies will probably appear in great numbers next season, and may do considerable damage.

I bring this matter before the farmers of the State thus early in my observations upon the fly in order that I may incite them to observe the insect, and to invite correspondence from them that may lead to a better knowledge of their distribution in this state and the amount of damage they cause. . 
